F. Reprod. Fert. (1968) 17, 173-175

\title{
HOMOSEXUALITY IN FEMALE RATS FOLLOWING TESTOSTERONE IMPLANTATION IN THE ANTERIOR HYPOTHALAMUS
}

\author{
G. DÖRNER, F. DÖGKE AND S. MOUSTAFA \\ Institute of Experimental Endocrinology, Charité, \\ Humboldt-University, 104 Berlin, Germany
}

(Received 15th March 1968, revised 27th May 1968)

Recently an experimental model of androgen-induced male homosexuality was produced. Castration of male rats within $24 \mathrm{hr}$ of birth causes the development of a 'female organization' of the hypothalamus. Doses of testosterone in the adults then activate the feminized hypothalamus of these animals. Male homosexuality, i.e. predominantly female sexual behaviour induced by androgen in genotypic and phenotypic males occurs (Dörner, 1967).

Although the homosexual behaviour was completely elicited in these animals, elements of heterosexual behaviour persisted (Dörner, Hinz, Seidler \& Fatschel, 1968). This partial dissociation in the organization of male and female mating behaviour suggested that separate neural areas may be responsible for the two patterns of behaviour, consistent with the observations of Goy \& Phoenix (1963) where hypothalamic lesions in female guinea-pigs affected mounting activity and lordosis, independently.

To test this possibility, precise quantities of crystalline testosterone propionate (TP) were stereotaxically implanted in the hypothalamus of post-puberally spayed female rats and in male rats castrated neonatally or after puberty according to a method described recently (Döcke, Dörner \& Voigt, 1968). The loci of the bilateral testosterone implants in the medial anterior or central hypothalamus were established by histological examination of diencephalic serial sections. Sexual behaviour of the animals was compared with that of similarly treated rats which, however, received subcutaneously injected androgen instead of intrahypothalamic TP implants when adult (Dörner, 1967).

The following results were obtained (Table 1):

(1) Implantation of $0.2 \mathrm{mg}$ TP in the medial pre-optic anterior hypothalamic region produced predominantly male, i.e. homosexual, behaviour in postpuberally spayed female rats (Table $1 ; \mathrm{Ia}$ and $\mathrm{Ib}$ ). These implants also elicited male behaviour in neonatally and post-puberally castrated males (Table 1; Ic and Id).

(2) Implantation of $0.2 \mathrm{mg}$ TP in the medial central hypothalamus resulted in predominantly female behaviour in post-puberally spayed females (Table 1; IIa), while similar implants were relatively ineffective in males castrated after puberty (Table 1 ; IIb).

(3) Implantation of $0.05 \mathrm{mg}$ TP in the anterior or central hypothalamus of 
TABLE 1

EFFECTS OF INTRAHYPOTHALAMIC TP IMPLANTATIONS GOMPARED WITH SUBCUTANEOUS TP INJECTIONS ON SEXUAL BEHAVIOUR OF POST-PUBERALLY SPAYED FEMALE AND NEONATALLY (1ST DAY OF LIFE) OR POST-PUBERALLY GASTRATED MALE RATS

\begin{tabular}{|c|c|c|c|c|}
\hline \multirow{2}{*}{ Group } & \multirow{2}{*}{ Treatment } & \multirow{2}{*}{$\begin{array}{l}\text { No. of } \\
\text { rats }\end{array}$} & \multirow{2}{*}{$\begin{array}{c}\text { No. of } \\
\text { tests }\end{array}$} & $\begin{array}{l}\text { No. of tests with } \\
\text { demonstrable: }\end{array}$ \\
\hline & & & & $\begin{array}{cc}\text { Male behaviour } & \text { Female behaviour } \\
(\text { mounting }) & (\text { lordosis })\end{array}$ \\
\hline I & $\begin{array}{l}\text { Implantation of } 0.2 \mathrm{mg} \text { TP in the } \\
\text { anterior hypothalamus of: }\end{array}$ & & & \\
\hline $\mathbf{a}$ & $\begin{array}{l}\text { Post-puberally spayed normal } \\
\text { females }\end{array}$ & 18 & 90 & $47 \stackrel{1}{P<0.001 *}^{0}$ \\
\hline b & $\begin{array}{l}\text { Post-puberally spayed females, } \\
\text { androgenized post-natally }(1 \cdot 25 \\
\text { mg TP on the 3rd day of life })\end{array}$ & 24 & 120 & $98 \stackrel{\longleftarrow_{P<0.001}}{7}$ \\
\hline c & Neonatally castrated males & 13 & 65 & $35 \leftarrow$ P<0.001 5 \\
\hline d & Post-puberally castrated males & 10 & 50 & $42 \stackrel{P<0.001}{-0}$ \\
\hline II & $\begin{array}{l}\text { Implantation of } 0.2 \mathrm{mg} \text { TP in the } \\
\text { central hypothalamus of: }\end{array}$ & & & \\
\hline $\mathbf{a}$ & Post-puberally spayed females & 15 & 45 & $\stackrel{P}{P<0.001} \longrightarrow 33$ \\
\hline b & Post-puberally castrated males & 11 & 44 & $5 \underset{P>0.05}{\longrightarrow} 0$ \\
\hline IIIa & $\begin{array}{l}\text { Implantation of } 0.05 \mathrm{mg} \mathrm{TP} \text { in the } \\
\text { anterior or central hypothalamus } \\
\text { of post-puberally spayed fe- } \\
\text { males }\end{array}$ & 12 & 48 & $0 \underset{P>0.05}{\stackrel{\longrightarrow}{\longrightarrow}} 0$ \\
\hline b & $\begin{array}{l}\text { Implantation of } 0.2 \mathrm{mg} \text { cholesterol } \\
\text { in the anterior or central hypo- } \\
\text { thalamus of post-puberally cas- } \\
\text { trated males }\end{array}$ & 16 & 32 & $0 \underset{P>0.05}{\longrightarrow} 0$ \\
\hline IV & $\begin{array}{l}\text { s.c. injections of daily } 1.0-0.25 \mathrm{mg} \\
\text { TP in: }\end{array}$ & & & \\
\hline a & Normal males & 10 & 40 & $37 \stackrel{\longleftarrow_{P<0.001}}{0} 0$ \\
\hline b & $\begin{array}{l}\text { Post-natally androgenized and } \\
\text { post-puberally spayed females }\end{array}$ & 14 & 56 & $39 \longleftarrow_{P<0.001} 8$ \\
\hline c & $\begin{array}{l}\text { Post-natally untreated and post- } \\
\text { puberally spayed females }\end{array}$ & 15 & 45 & $8 \underset{P<0.001}{\longrightarrow} 33$ \\
\hline $\mathrm{d}$ & Neonatally castrated males & 21 & 84 & 43 $\underset{P<0.01}{\longrightarrow} 62$ \\
\hline
\end{tabular}

In each mating test the rat was exposed for $5 \mathrm{~min}$ to: (1) an oestrous female, and (2) a vigorous male. $* x$ test.

spayed females did not produce behavioural effects (Table 1; IIIa), neither did cholesterol implants in these hypothalamic regions of castrate males (Table $1 ;$ IIIb). 
(4) Subcutaneous TP injections in adulthood caused predominantly male behaviour in normal males and post-natally androgenized females (Table 1; IVa and IVb), but predominantly female behaviour in post-natally untreated females and neonatally castrated males (Table 1; IVc and IVd).

A systemic effect of the intrahypothalamic testosterone implants was excluded by the fact that in post-puberally castrated animals the weights of prostates and seminal vesicles of the TP-implanted animals were not significantly different from those of cholesterol-implanted controls.

Our data seem to be consistent with the following hypothesis: In genetic male and female rats, 'Anlagen' (precursors) for both a male and a female mating centre are localized in the anterior and central hypothalamus respectively. A low androgen level during the critical period of hypothalamic organization, e.g. in neonatally castrated males or intact females, effects only a more or less rudimentary differentiation of the anterior male centre but a complete differentiation of the central female centre. Conversely, a high androgen level in this critical period in intact males or post-natally androgenized females causes a more or less complete differentiation of the anterior male centre and a slight, if any, differentiation of the central female mating centre. In the post-puberal period androgens display an activating effect on both centres.

On this view, the direction of the sex drive is normally determined by the dominant male or female mating centre organized during the critical phase of androgen-dependent differentiation. But it can be reversed by appropriate hormonal stimulation of the undifferentiated centre in the post-puberal period, e.g. by testosterone implants in the male centre of female rats, eliciting homosexual behaviour.

This hypothesis is also consistent with the patterns of sexual behaviour shown after different hypothalamic lesions in rats (Law \& Meagher, 1958) or sheep (Radford, 1967) and after intrahypothalamic testosterone implantations in rats (Davidson, 1966) or rabbits (Palka \& Sawyer, 1966).

\section{REFERENCES}

Davidson, J. M. (1966) Activation of the male rat's sexual behaviour by intracerebral implantation of androgen. Endocrinology, 79, 783.

DöCKe, F., Dörner, G. \& VoIGT, K.-H. (1968) A possible mechanism of the ovulation-inhibiting effect of chlormadinone acetate in the rat. F. Endocr. 41, 353.

Dörner, G. (1967) Tierexperimentelle Untersuchungen zur Frage einer hormonellen Pathogenese der Homosexualität. Acta biol. med. germ. 9, 569 .,

Dörner, G., Hinz, G., Seidler, C. \& Fatschel, J. (1968) Partielle Dissoziation in der Differenzierung des männlichen und weiblichen Sexualverhaltens. Acta biol. med. germ. (In press).

Goy, R. W. \& Phoenrx, C. H. (1963) Hypothalamic regulation of female sexual behaviour; establishment of behavioural oestrus in spayed guinea-pigs following hypothalamic lesions. $\mathcal{F}$. Reprod. Fert. 5, 23.

Law, T. \& Meagher, W. (1958) Hypothalamic lesions and sexual behavior in the female rat. Science, N.Y. 128, 1626.

PALKA, Y. S. \& SAwYer, C. H. (1966) Induction of estrous behaviour in rabbits by hypothalamic implantation of testosterone. Am. F. Physiol. 211, 225.

RADFORD, H. M. (1967) The effect of hypothalamic lesions on reproductive activity in sheep. F. Endocr. $39,415$. 